\begin{tabular}{|c|c|c|c|c|c|}
\hline JRL & Vol. 14 & No.1 & Hal. 1-13 & $\begin{array}{c}\text { Jakarta, } \\
\text { Juni 2021 }\end{array}$ & $\begin{array}{r}\text { p-ISSN : 2085.38616 } \\
\text { e-ISSN : 2580-0442 }\end{array}$ \\
\hline
\end{tabular}

\title{
KONDISI KUALITAS DAN KEBUTUHAN AIR DESA KAWASI DI KAWASAN PERTAMBANGAN NIKEL PULAU OBI
}

\author{
Satmoko Yudo dan Taty Hernaningsih \\ Pusat Teknologi Lingkungan - Badan Pengkajian dan Penerapan Teknologi \\ Gedung Geostech 820 Lt.2, Kawasan Puspiptek, Tangerang Selatan, Banten 15314 \\ Email: satmoko.yudo@bppt.go.id dan taty.hernaningsih@bppt.go.id
}

\begin{abstract}
Abstrak
Pulau Obi memiliki potensi sumberdaya alam sektor pertambangan yang cukup banyak. Aktivitas penambangan nikel di Pulau Obi dilakukan dengan cara pengupasan tanah menimbulkan berbagai dampak terhadap kualitas lingkungan. Salah satu dampaknya yang dikhawatirkan adalah perubahan kualitas airtanah yang berada di sekitar lokasi pertambangan. Air mengalir yang berasal dari lokasi pertambangan nikel membawa mineralmineral berat yang akan masuk ke aliran sungai dan terinfiltrasi ke dalam tanah, sehingga akan mempengaruhi kualitas airtanah di sekitar lokasi penambangan. Desa Kawasi adalah salah satu pemukiman penduduk yang terletak di sekitar lokasi penambangan. Kebutuhan air untuk minum dan lainnya diambil dari mata air Kawasi yang juga berada di sekitar pertambangan. Dalam kegiatan ini akan diulas kondisi kualitas air dan jumlah kebutuhan air serta kondisi sanitasi penduduk di Desa Kawasi. Kegiatan ini dilakukan dengan melakukan survei pengambilan sampel air, pengukuran debit air dan menghitung kebutuhan air bersih di mata air Kawasi serta wawancara kepada penduduk setempat. Secara umum hasil survei menunjukkan bahwa kualitas air masih di bawah baku mutu yang dipersyaratkan sebagai air bersih serta debit air yang banyak di mata air Kawasi.
\end{abstract}

Kata kunci : Kualitas air, kebutuhan air bersih, pertambangan nikel

\section{Condition Of Water Quality And Demand In The Kawasi Village In The Nickel Mining Area On The Obi Island}

\begin{abstract}
Obi Island has a lot of potential natural resources in the mining sector. Nickel mining activities on Obi Island are carried out by stripping the soil causing various impacts on environmental quality. One of the worrying impacts is the change in groundwater quality around the mining site. The discharge water that flow from the nickel mining location contains heavy minerals that will enter the river flow and infiltrate the ground, so that it will affect the quality of groundwater around the mining site. Kawasi Village is one of residential area located around the mining site. Water demand for drinking and other needs is taken from the Kawasi spring which is also around the mine. In this activity, the condition of water quality and the amount of water needed will be reviewed as well as the sanitation conditions of the people in Kawasi Village. This activity was carried out by conducting a water sampling survey, measuring water discharge and calculating the need for clean water in the Kawasi springs as well as interviews with local residents. In general, the survey results show that the water quality is still below the quality standard required for clean water and that there is a lot of water discharge at the Kawasi spring.
\end{abstract}

Keywords : water quality, clean water requirement, nickel mining 


\section{PENDAHULUAN \\ 1.1. Latar Belakang}

Searah dengan pelaksanaan Undangundang jelas berimplikasi pada tegasnya wewenang tiap kabupaten untuk secara mandiri mengurusi wilayahnya sendiri (1). Salah satu andalan daerah Kabupaten Halmahera Selatan adalah pemanfaatan sumber daya alamnya. Diantara perusahaan yang sedang berkembang, salah satunya mempunyai wilayah pertambangan nikel pada areal lahan pengusahaan di Desa Kawasi, Kecamatan Obi Kabupaten Halmahera Selatan, Provinsi Maluku Utara. Wilayah tersebut berada pada Daerah Aliran Sungai Toguraci yang termasuk Wilayah Sungai di Pulau Obi. Untuk memenuhi kebutuhan air kegiatan pertambangan tersebut dilakukan dengan memanfaatkan keberadaan air dari Danau Karo yang terletak kurang lebih $5 \mathrm{~km}$ di sebelah Utara. Danau Karo yang luas DASnya sekitar 65.611.110 $\mathrm{m}^{2}$, mempunyai sungai utama panjangnya mencapai $14,4 \mathrm{~km}$, memasok air dengan kapasitas 505,00 liter/detik (2).

$$
\text { Seiring dengan rencana }
$$

pengembangan kegiatan pertambangan, maka kebutuhan air dari Danau Karo semakin meningkat. Dengan demikian, total kebutuhan air kegiatan pertambangan di lokasi ini per tahun akan mencapai sebesar 22,21 juta $\mathrm{m}^{3}$. Dengan meningkatnya kebutuhan air pada tahun 2020, maka perlu diperhitungkan bagaimana perubahan kesetimbangan air Danau Karo pada saat itu, termasuk penggunaan air Danau Karo oleh kebutuhan perusahaan yang akan membangun smelter yang membutuhkan air cukup besar. Selain itu untuk pelaksanaan CSR, perusahaan pertambangan menyediakan kebutuhan air untuk masyarakat disekitarnya, diantaranya untuk Desa Kawasi. Untuk memenuhi kebutuhan air, masyarakat Desa Kawasi sudah menggunakan mata air Kawasi sejak lama. Dalam rangka CSR tersebut, perusahaan pertambangan tersebut sejak membangun pertambangan didekat desa tersebut telah menyediakan pelayanan kemasyarakat dengan memfasilitasi sistem distribusi untuk mengalirkan air dari mata air tersebut ke rumah-rumah masyarakat tanpa biaya.

Dengan penggunaan sumber air yang terus bertambah, potensi sumber air dari sumber Danau Karo dan mata air Kawasi pada saat ini terus berkurang. Berkurangnya sumber air untuk penduduk ini apabila tidak ditanggulangi secara dini maka akan mempengaruhi kesehatan masyarakat. Salah satu solusi mengatasi masalah ini pada tahap awal adalah dengan melakukan kajian tentang kondisi kualitas air dan kebutuhan air masyarakat Desa Kawasi yang menggunakan mata air Kawasi. Sesuai dengan dasar pertimbangan tersebut aka untuk mendukung kajian tersebut akan dilakukan survei untuk mengetahui kondisi kualitas air mata airnya dan menghitung besarnya kebutuhan air masyarakat yang berada di Desa Kawasi, Kec. Obi, Kab. Halmahera Selatan, Provinsi Halmahera.

\subsection{Tujuan}

Tujuan yang ingin dicapai dalam kegiatan ini adalah untuk mengetahui kondisi kualitas mata air, kebutuhan dan pemakaian air bersih serta sanitasi lingkungan dan kesehatan penduduk Desa Kawasi, Kecamatan Obi, Provinsi Halmahera Selatan. Manfaat hasil penelitian ini dapat menjadi sumber informasi terciptanya good mining practice bagi kegiatan tambang nikel dan masyarakat yang berada di sekitar kawasan penambangan serta para peneliti lainnya.

\section{BAHAN DAN METODOLOGI}

\subsection{Lokasi Kegiatan}

Survei dilakukan pada bulan September 2019 dan lokasi survei ditentukan berdasarkan kepada lokasi desa yang terdekat dari pertambangan nikel yaitu Desa Kawasi di Kecamatan Obi, Provinsi Halmahera Selatan. Desa Kawasi adalah desa dengan luas daerah yang cukup besar yaitu sebesar $284,60 \mathrm{~km}^{2}$, dengan ketinggian dari permukaan laut $<500 \mathrm{~m}$. Jumlah penduduk Desa Kawasi tahun 2018 sebesar 1.148 jiwa dengan kepadatan penduduk hanya 4 jiwa $/ \mathrm{km}^{2}(3)$. Sedangkan lokasi mata 
air berada sekitar 500 meter dari Desa Kawasi arah barat daya.

\subsection{Bahan dan Alat}

Bahan yang digunakan dalam kegiatan ini yaitu sumber air dari mata air Kawasi, jumlah penduduk dan sejumlah kuesioner untuk bahan wawancara kepada masyarakat Desa Kawasi. Sedangkan alat yang digunakan adalah peralatan APD, peralatan pengambilan sample air, alat pengukur debit, dll.

\subsection{Metode Penelitian}

Kegiatan ini meliputi survei, pengambilan sample air dan menganalisa hasil uji laboratorium yang mengacu pada Peraturan Menteri Kesehatan RI No. 32 tahun 2017. Untuk pengukuran debit aliran mata air Kawasi digunakan dengan metode apung dan perhitungan kebutuhan air dengan mengetahui jumlah penduduk. Untuk memprediksi jumlah penduduk 10-20 tahun kedepan digunakan metode Aritmatik dan Geometrik. Serta untuk mengetahui kondisi pemakaian air bersih, sanitasi lingkungan dan kesehatan masyarakat digunakan metoda wawancara dengan alat bantu kuesioner.

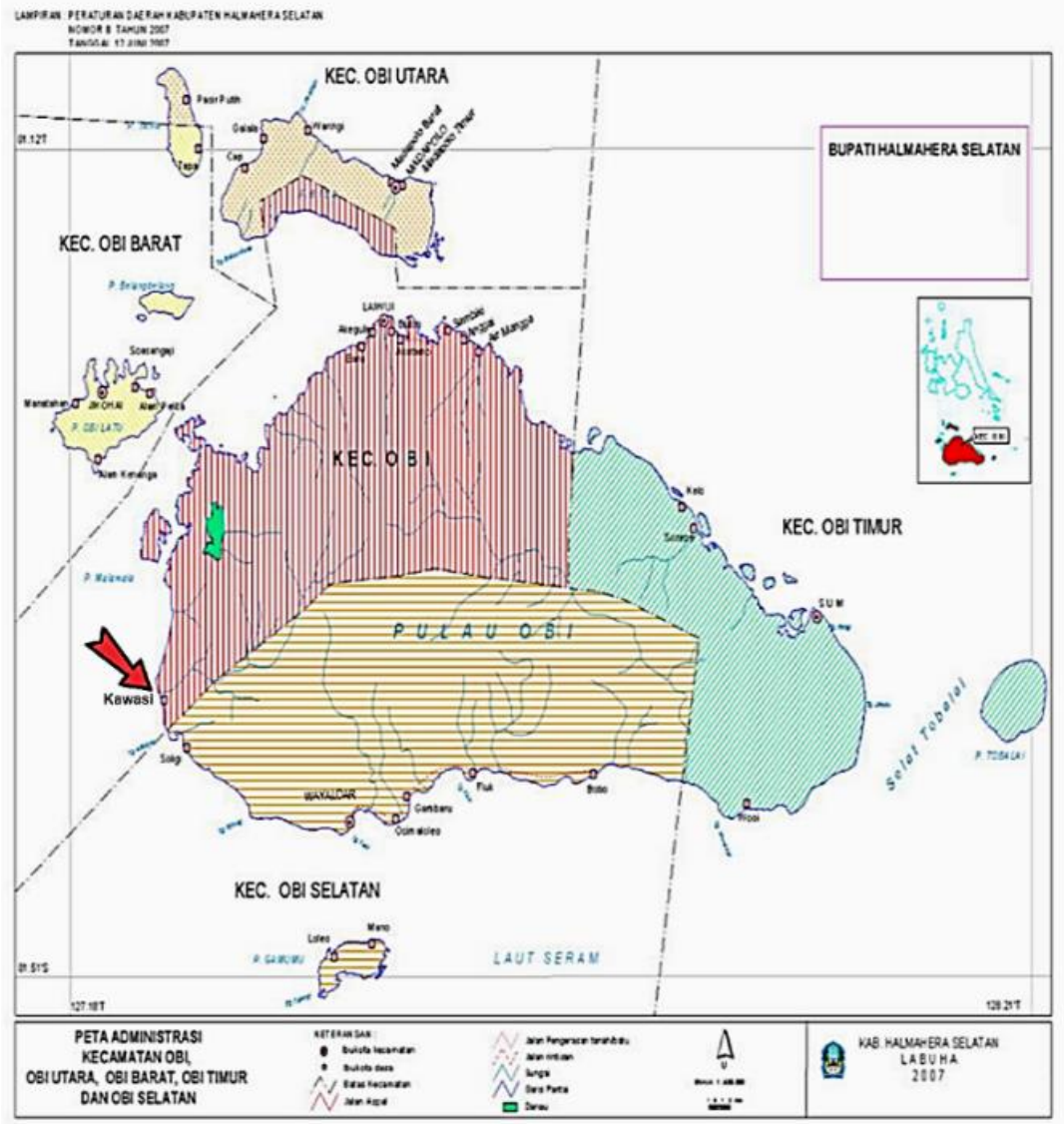

(Sumber: Kecamatan Obi Dalam Angka 2018, BPS Kabupaten Halmahera Selatan) Gambar 1. Peta Lokasi Desa Kawasi, Kec. Obi, Kab. Halmahera Selatan 


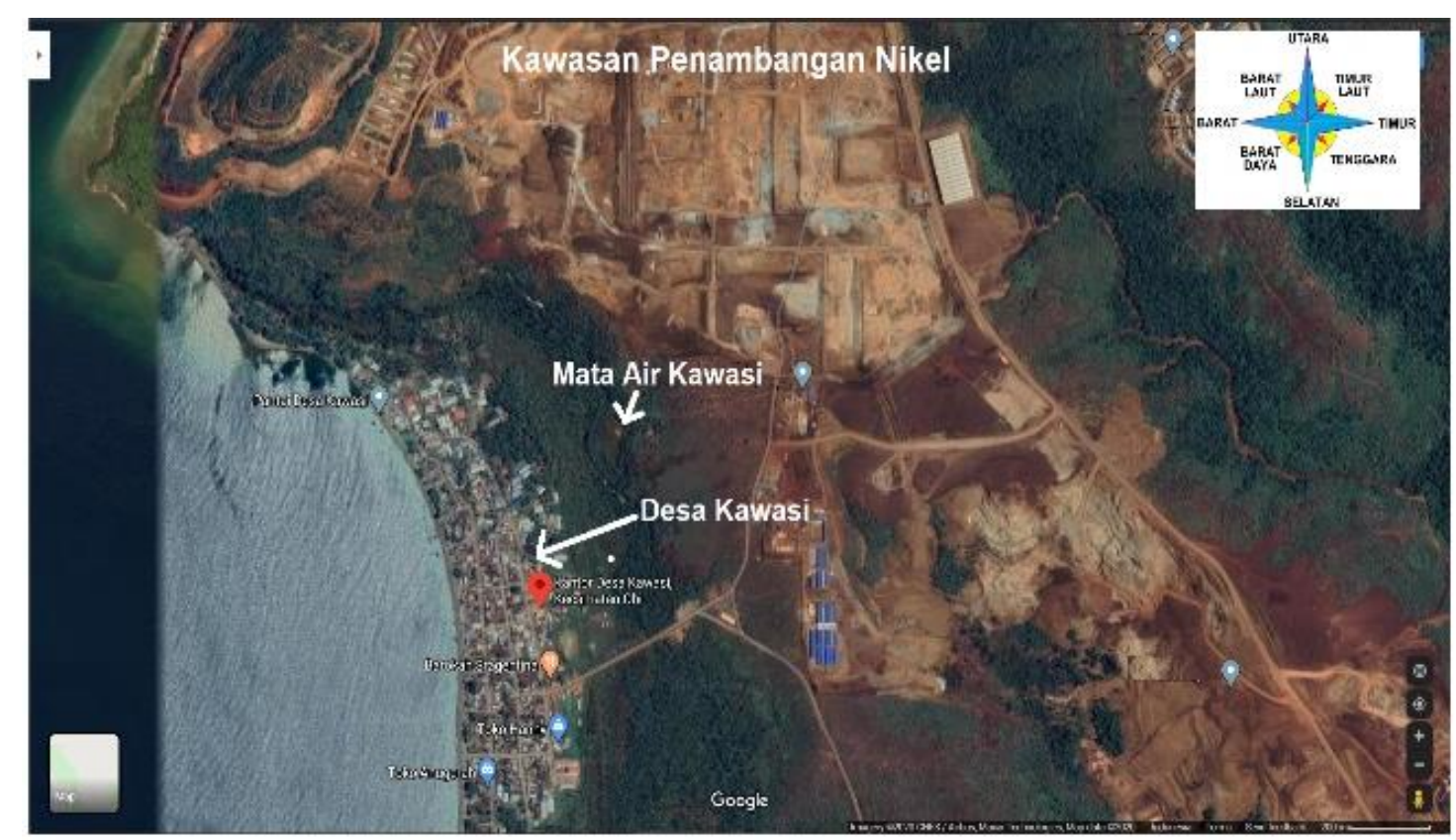

(Sumber: maps.google.com)

Gambar 2. Lokasi Mata Air Kawasi dan Desa Kawasi Serta Kawasan Penambangan Nikel

\section{HASIL DAN PEMBAHASAN Mata Air Kawasi}

Mata air Kawasi terletak di sebelah timur laut dan berjarak sekitar 500 meter dari Desa Kawasi dengan koordinat sekitar $323717 \mathrm{mE}$ dan $9829372 \mathrm{mS}$ (UTM Zona 52S). Mata air Kawasi merupakan mata air dengan debit yang paling besar pada area sekitar perusahaan pertambangan. Air yang berasal dari mata air ini dimanfaatkan untuk sumber air minum dan kebutuhan sehari-hari seperti mandi, cuci, dan kakus (MCK) oleh warga Desa Kawasi yang dialirkan melalui pipa-pipa (Gambar 2).

LAPI ITB melakukan studi pada tahun 2018 menyebutkan sumber mata air ini mempunyai debit 138 liter/detik (4). Selain itu studi yang dilakukan tersebut menjelaskan bahwa sumber mata air tersebut dapat berasal atau sama dengan aliran airtanah Danau Karo. Untuk mencegah adanya penurunan debit yang mensuplai kebutuhan domestik ini, dapat dilakukan dengan memperbesar penampungan air sehingga penyediaan air bisa mencukupi pada saat kebutuhan puncak. Pada saat ini penduduk Desa
Kawasi mendapat pelayanan air dari perusahaan pertambangan yang bersumber dari mata air Kawasi dengan pengaliran air dilakukan secara gravitasi dan tanpa harus membayar air. Distribusi air dilakukan dengan menggunakan beberapa pipa ke pemukiman warga, yaitu pipa ukuran 4.5 inch sebanyak 3 buah, pipa ukuran 2 inch sebanyak 4 buah, dan pipa ukuran 3 inch sebanyak 2 buah.

Untuk mengetahui debit mata air saat ini, telah dilakukan pengukuran dengan metode apung (5) dengan menggunakan persamaan seperti dibawah ini:

$$
\begin{aligned}
& Q=A \times(k \times U) \\
& Q=A \times V
\end{aligned}
$$

Dimana:

$Q=$ debit aliran ( $\mathrm{m}^{3} /$ detik).

$A=$ luas penampang basah $\left(\mathrm{m}^{2}\right)$.

$k=$ koefisien pelampung.

$U=$ kecepatan pelampung ( $\mathrm{m} /$ detik).

$V=$ kecepatan aliran (m/detik).

Dari hasil pengukuran diperoleh:

Kecepatan pelampung:

$\mathrm{U}=\mathrm{S} / \mathrm{t}$ rata 
$=4 \mathrm{~m} / 6,19$ detik

$=0,65 \mathrm{~m} /$ detik

Luas penampang rata-rata:

$A=$ Lebar $x$ Kedalaman (rata2)

$=2,08 \mathrm{~m} \times 0,14 \mathrm{~m}$

$=0,283 \mathrm{~m}^{2}$

Kecepatan aliran:

$\mathrm{V}=\mathrm{k} \times \mathrm{U}$

$=0,65 \times 0,65$

$=0,423 \mathrm{~m} /$ detik

Debit mata air Kawasi:

$$
\begin{aligned}
Q & =A \times V \\
& =0,283 \times 0,423 \\
& =0,119 \mathrm{~m}^{3} / \text { detik } \\
& =119 \text { liter } / \text { detik }
\end{aligned}
$$

Dari hasil perhitungan debit di lokasi mata air Kawasi diperoleh sebesar 119 liter/detik. Potensi sumber air dari mata air ini cukup besar, sedangkan yang digunakan untuk memenuhi kebutuhan air penduduk Desa Kawasi relatif kecil, sebagian besar air tersebut terbuang ke laut. Air tersebut dapat dimanfaatkan oleh perusahaan tambang dengan membuat bak atau kolam penampung untuk digunakan untuk keperluan penduduk pada saat musim kemarau atau digunakan oleh perusahaan pada saat kekurangan air.

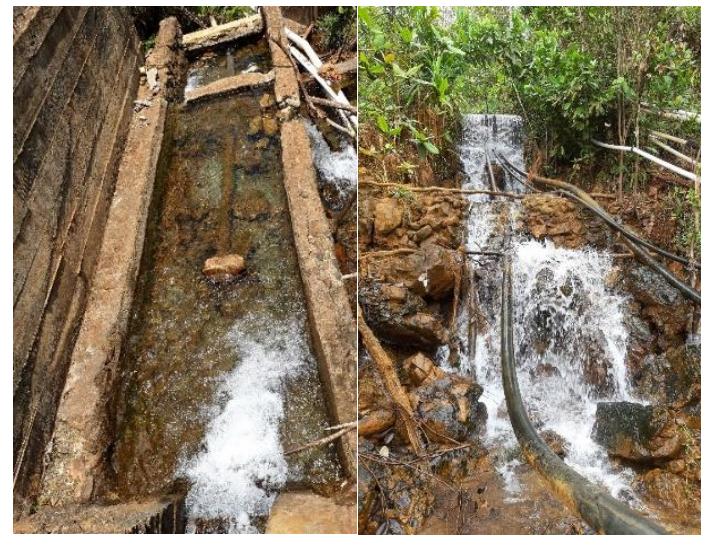

(Sumber: Tim Survei BPPT, 2019)

Gambar 3. Bak penampung dan perpipaan dari Mata Air Kawasi untuk disalurkan ke Desa Kawasi

\section{Kualitas Air Mata Air Kawasi}

Hasil dari pengukuran LAPI ITB terhadap sifat fisik-kimia air di lokasi mata air Kawasi menunjukkan nilai TDS yang relatif kecil, yaitu sebesar 72,6 ppm (4). Hasil pengukuran terhadap parameter lainnya, adalah sebagai berikut: temperatur $26.1^{\circ} \mathrm{C}$, electrical conductivity 105,7 $\mu \mathrm{S} / \mathrm{cm}, \mathrm{pH} 6-7$ (netral), dan salinitas $0.01 \%$.

Sedangkan pengukuran kualitas air mata air Kawasi tahun 2019, berdasarkan hasil uji sampel yang diambil di lokasi overflow mata air kualitasnya meningkat dan tidak ditemukan adanya parameter fisika dan kimia yang melebihi baku mutu yang ditetapkan sesuai dengan Permenkes RI No. 32 tahun 2017 (6). Secara keseluruhan kualitas air mata air masih sangat baik, hal ini juga juga terlihat dari nilai TDS masih jauh dari baku mutu yang ditetapkan, yaitu sebesar 92 , sedangkan baku mutunya 1.000 $\mathrm{mg} / \mathrm{l}$ demikian juga dengan parameter yang lainnya seperti kekeruhan $0.02 \mathrm{mg} / \mathrm{l}$, fluorida sebesar $0.030 \mathrm{mg} / \mathrm{l}$ dan sulfat $0.54 \mathrm{mg} / \mathrm{l}$ dengan baku mutu yang ditetapkan $400 \mathrm{mg} / \mathrm{l}$.

Analisa secara biologi yaitu dari parameter total coliform masih jauh di bawah baku mutu yang ditetapkan Permenkes RI No. 32 tahun 2017 dengan nilai $<1,8$ CFU/100 ml dan baku mutunya $50 \mathrm{CFU} / 100$

\begin{tabular}{|c|c|c|c|c|}
\hline No & Parameter & Satuan & $\begin{array}{l}\text { Baku } \\
\text { Mutu }\end{array}$ & $\begin{array}{c}\text { Hasil } \\
\text { Air } \\
\text { Baku }\end{array}$ \\
\hline & Fisika & & & \\
\hline 1 & Turbidity & NTU & 25 & 0,02 \\
\hline 2 & Warna & $\mathrm{TCU}$ & 50 & $<1$ \\
\hline 3 & $\begin{array}{l}\text { Jumlah zat } \\
\text { padat terlarut } \\
\text { (TDS) }\end{array}$ & $\mathrm{mg} / \mathrm{l}$ & 1000 & 92 \\
\hline 4 & Temperatur & ${ }^{\circ} \mathrm{C}$ & $\begin{array}{c}\text { Suhu } \\
\text { Udara } \pm \\
3\end{array}$ & 26 \\
\hline 5 & Rasa & $\begin{array}{c}\text { Tidak } \\
\text { berasa }\end{array}$ & & tb \\
\hline \multirow[t]{2}{*}{6} & Bau & $\begin{array}{c}\text { Tidak } \\
\text { berbau }\end{array}$ & & tb \\
\hline & Kimia & & & \\
\hline 1 & $\mathrm{pH}$ & - & $6-9$ & 6,08 \\
\hline 2 & Flourida, $\mathrm{F}$ & $\mathrm{mg} / \mathrm{l}$ & 1,5 & 0,03 \\
\hline
\end{tabular}
$\mathrm{ml}$, tetapi $e$-coli berjumlah $<1,08 \mathrm{CFU} / 100 \mathrm{ml}$.

\section{Tabel 1. Hasil Analisa Kualitas Air Mata Air Kawasi}




\begin{tabular}{|c|c|c|c|c|}
\hline 3 & $\begin{array}{l}\text { Kesadahan } \\
\text { jumlah } \\
\left(\mathrm{CaCO}_{3}\right)\end{array}$ & $\mathrm{mg} / \mathrm{l}$ & 500 & 53,34 \\
\hline 4 & Nitrat $\left(\mathrm{NO}_{3}-\mathrm{N}\right)$ & $\mathrm{mg} / \mathrm{l}$ & 10 & 1,599 \\
\hline 5 & Nitrit $\left(\mathrm{NO}_{2}-\mathrm{N}\right)$ & $\mathrm{mg} / \mathrm{l}$ & 1 & 0,014 \\
\hline 6 & Cianida, CN & $\mathrm{mg} / \mathrm{l}$ & 0,1 & $\begin{array}{c}<0,00 \\
2\end{array}$ \\
\hline 7 & $\begin{array}{l}\text { Surfactans, } \\
\text { MBAS }\end{array}$ & $\mathrm{mg} / \mathrm{l}$ & 0,005 & $\begin{array}{c}<0,01 \\
4\end{array}$ \\
\hline 8 & Sulfat, $\mathrm{SO}_{4}$ & $\mathrm{mg} / \mathrm{l}$ & 400 & 0,54 \\
\hline 9 & $\begin{array}{l}\text { Total organik, } \\
\mathrm{KMnO}_{4}\end{array}$ & $\mathrm{mg} / \mathrm{l}$ & 10 & 0,30 \\
\hline & Biologi & & & \\
\hline 1 & Total Coliform & $\begin{array}{c}\mathrm{CFU} / 100 \\
\mathrm{~mL}\end{array}$ & 50 & $<1,8$ \\
\hline 2 & E Coli & $\begin{array}{l}\text { CFU/10 } \\
0 \mathrm{~mL}\end{array}$ & 0 & $<1,08$ \\
\hline
\end{tabular}

Keterangan : Baku Mutu sesuai Peraturan Menteri Kesehatan RI No. 32 tahun 2017, tentang baku mutu air bersih untuk keperluan higiene sanitasi.

Menurut hasil studi LAPI ITB penempatan lokasi pengembangan tambang di dekat lokasi mata air kawasi akan memberikan dampak relatif kecil terhadap sumber resapan mata air Kawasi. Dimana berdasarkan hasil studi ini, bahwa sumber resapan mata air Kawasi berasal dari Danau Karo atau elevasi lebih tinggi. Namun yang harus menjadi perhatian dan memungkinkan memberikan dampak signifikan adalah rencana penggalian di dekat lokasi mata air Kawasi. Jika penggalian dilakukan hingga memotong aliran airtanah yang berhubungan dengan mata air Kawasi, maka akan muncul mata air depresi (7) dan kuantitas mata air Kawasi akan terganggu.

\section{Jumlah Penduduk}

Jumlah penduduk Desa Kawasi menurut data tahun 2017 adalah 1.004 jiwa (8), sedangkan jumlah penduduk tahun 2010 s.d. 2017 dapat dilihat pada Tabel 2.

Tabel 2. Jumlah Penduduk Desa Kawasi

\begin{tabular}{|c|c|}
\hline Tahun & $\begin{array}{c}\text { Jumlah } \\
\text { Penduduk }\end{array}$ \\
\hline 2010 & 767 \\
\hline 2011 & 870 \\
\hline 2012 & 966 \\
\hline 2013 & 990 \\
\hline 2014 & 972 \\
\hline
\end{tabular}

\begin{tabular}{|c|c|}
\hline 2015 & 1.022 \\
\hline 2016 & 1.118 \\
\hline 2017 & 1.004 \\
\hline Kecamatan Obi Dalam Angka 2010-2017.
\end{tabular}

Pertumbuhan jumlah penduduk akan mempengaruhi jumlah kebutuhan airnya (9). Begitupun kebutuhan air penduduk Desa Kawasi. Untuk mengetahui jumlah kebutuhan air penduduk Desa Kawasi di masa datang, perlu memproyeksikan jumlah penduduk untuk 10 s.d. 20 tahun kedepan. Perhitungan proyeksi penduduk menggunakan metode Aritmatik dan Geometrik (10).

Rumus Aritmatik yang digunakan :

$$
P t=P o(1+r * t)
$$

Dimana :

$P t=$ Jumlah penduduk pada tahun ke t.

$P o=$ Jumlah penduduk pada dasar.

$t=$ Periode waktu proyeksi.

$r \quad=$ Angka pertumbuhan penduduk tiap tahun.

Rumus Geometrik yang digunakan :

$$
P t=P t(1+r)^{t}
$$

Dimana :

$P t=$ Jumlah penduduk pada tahun $\mathrm{t}$.

$P o=$ Jumlah penduduk pada tahun dasar.

$t=$ Jumlah tahun proyeksi.

$r=$ Angka pertumbuhan penduduk.

Tabel 3. Prediksi Jumlah Penduduk Desa Kawasi

\begin{tabular}{|c|c|c|}
\hline \multirow{2}{*}{ Tahun } & \multicolumn{2}{|c|}{ Jumlah Penduduk } \\
\cline { 2 - 3 } & $\begin{array}{c}\text { Arit- } \\
\text { Metik }\end{array}$ & $\begin{array}{c}\text { Geo- } \\
\text { Metrik }\end{array}$ \\
\hline 2018 & 1.353 & 1.359 \\
\hline 2019 & 1.392 & 1.406 \\
\hline 2020 & 1.431 & 1.454 \\
\hline 2025 & 1.586 & 1.663 \\
\hline 2030 & 1.780 & 1.968 \\
\hline 2035 & 1.973 & 2.329 \\
\hline 2040 & 2.167 & 2.756 \\
\hline
\end{tabular}


Dari hasil analisis Regresi Linear menggunakan aplikasi SPPS V.21 pada jumlah penduduk dengan 2 metode diatas, diambil nilai Standard Error yang terkecil adalah nilai prediksi jumlah penduduk dengan metode Geometrik.

\section{Kebutuhan Air Domestik}

Kebutuhan air di Desa Kawasi Pulau Obi merupakan kebutuhan air domestik yang digunakan untuk keperluan rumah tangga tidak hanya terbatas untuk memasak, minum, dan mandi, namun juga untuk hampir setiap aktivitas yang memerlukan air seperti cuci motor, kebersihan, siram tanaman dan lainlain.
Analisis sektor kebutuhan air domestik untuk masa mendatang dilaksanakan dengan dasar analisis pertumbuhan penduduk pada desa yang direncanakan. Kebutuhan air domestik Desa Kawasi sesuai Kriteria Perencanaan Ditjen Cipta Karya Dinas PU 1996 (11), maka kebutuhan air domestik mengambil perbandingan Sambungan Rumah (SR) dengan Hidran Umum (HU) sebesar 70:30. Dimana kebutuhan SR adalah 60 liter/orang/hari dan $\mathrm{HU}$ adalah 30 liter/orang/hari. Perhitungan ini dilakukan untuk mengantisipasi adanya penggunaan sambungan rumah di Desa Kawasi pada masa mendatang.

Tabel 4. Kebutuhan Air Domestik

\begin{tabular}{|c|c|c|c|}
\hline \multirow{2}{*}{ Tahun } & $\begin{array}{c}\text { Jumlah } \\
\text { Penduduk }\end{array}$ & \multicolumn{2}{|c|}{$\begin{array}{c}\text { Kebutuhan Air } \\
\text { Domestik Penduduk }\end{array}$} \\
\cline { 2 - 4 } & orang & liter/hari & liter/detik \\
\hline 2018 & 1.359 & $69.320,16$ & 0,8023 \\
\hline 2019 & 1.406 & $71.693,01$ & 0,8298 \\
\hline 2020 & 1.454 & $74.147,09$ & 0,8582 \\
\hline 2025 & 1.663 & $84.832,70$ & 0,9819 \\
\hline 2030 & 1.968 & $100.380,59$ & 1,1618 \\
\hline 2035 & 2.329 & $118.778,06$ & 1,3747 \\
\hline 2040 & 2.756 & $140.547,36$ & 1,6267 \\
\hline
\end{tabular}

\section{Kebutuhan Air Non Domestik}

Sedangkan kebutuhan air non domestik meliputi kebutuhan air untuk perkantoran, sekolah, pendidikan, rumah ibadah, rumah sakit, pertokoan, dan lainnya.
Untuk analisis kebutuhan air non domestik dihitung berdasarkan standar perencanaan air bersih perdesaan yaitu $5 \%$ dari kebutuhan air domestik.

Tabel 5. Kebutuhan Air Non Domestik

\begin{tabular}{|c|c|c|c|}
\hline \multirow{2}{*}{ Tahun } & Jumlah & $\begin{array}{c}\text { Kebutuhan } \\
\text { Air } \\
\text { Domestik }\end{array}$ & $\begin{array}{c}\text { Kebutuhan } \\
\text { Air Non } \\
\text { Domestik }\end{array}$ \\
\cline { 2 - 4 } & orang & liter/detik & liter/detik \\
\hline 2018 & 1.359 & 0,8023 & 0,0401 \\
\hline 2019 & 1.406 & 0,8298 & 0,0415 \\
\hline 2020 & 1.454 & 0,8582 & 0,0429 \\
\hline 2025 & 1.663 & 0,9819 & 0,0491 \\
\hline 2030 & 1.968 & 1,1618 & 0,0581 \\
\hline
\end{tabular}




\begin{tabular}{|l|l|l|l|}
\hline 2035 & 2.329 & 1,3747 & 0,0687 \\
\hline 2040 & 2.756 & 1,6267 & 0,0813 \\
\hline
\end{tabular}

\section{Kehilangan Air}

Kehilangan air umumnya diakibatkan karena terjadi kebocoran air pada pipa transmisi dan distribusi serta kesalahan dalam pembacaan meter air. Jumlah besarnya kehilangan air berdasarkan kepada perencanaan sistem penyediaan air bersih pedesaan yaitu sebesar $15 \%$ dari kebutuhan rata-rata dimana kebutuhan rata-rata adalah sejumlah dari kebutuhan air domestik ditambah dengan kebutuhan air non domestik.

Tabel 6. Kebutuhan Kehilangan Air

\begin{tabular}{|c|c|c|c|}
\hline \multirow{2}{*}{ Tahun } & $\begin{array}{c}\text { Kebutuhan } \\
\text { Air } \\
\text { Domestik }\end{array}$ & $\begin{array}{c}\text { Kebutuhan } \\
\text { Air Non } \\
\text { Domestik }\end{array}$ & $\begin{array}{c}\text { Kehilangan } \\
\text { Air 15\% }\end{array}$ \\
\cline { 2 - 4 } & liter/detik & liter/detik & liter/detik \\
\hline 2018 & 0,8023 & 0,0401 & 0,1264 \\
\hline 2019 & 0,8298 & 0,0415 & 0,1307 \\
\hline 2020 & 0,8582 & 0,0429 & 0,1352 \\
\hline 2025 & 0,9819 & 0,0491 & 0,1547 \\
\hline 2030 & 1,1618 & 0,0581 & 0,1830 \\
\hline 2035 & 1,3747 & 0,0687 & 0,2165 \\
\hline 2040 & 1,6267 & 0,0813 & 0,2562 \\
\hline
\end{tabular}

Berdasarkan hasil perhitungan kebutuhan air domestik, non domestik serta kehilangan air, maka kebutuhan total air penduduk Desa Kawasi pada tahun 2035 dan
2040 adalah sebesar 1,6599 liter/detik dan 1,9642 liter/detik.

Tabel 7. Kebutuhan Air Total Desa Kawasi

\begin{tabular}{|c|c|c|c|}
\hline \multirow{2}{*}{ Tahun } & $\begin{array}{c}\text { Domestik } \\
\text { \& Non } \\
\text { Domestik }\end{array}$ & $\begin{array}{c}\text { Kehilangan } \\
\text { Air 15\% }\end{array}$ & Debit Total \\
\cline { 2 - 4 } & liter/detik & liter/detik & liter/detik \\
\hline 2018 & 0,8424 & 0,1264 & 0,9688 \\
\hline 2019 & 0,8713 & 0,1307 & 1,0020 \\
\hline 2020 & 0,9011 & 0,1352 & 1,0363 \\
\hline 2025 & 1,0310 & 0,1547 & 1,1857 \\
\hline 2030 & 1,2199 & 0,1830 & 1,4029 \\
\hline 2035 & 1,4434 & 0,2165 & 1,6599 \\
\hline 2040 & 1,7080 & 0,2562 & 1,9642 \\
\hline
\end{tabular}


Tabel 8 Kriteria dan Standar Kebutuhan Air

\begin{tabular}{|c|c|c|c|c|c|c|}
\hline \multirow{3}{*}{ No } & \multirow{3}{*}{ URAIAN / KRITERIA } & \multicolumn{5}{|c|}{ KATEGORI KOTA BERDASARKAN } \\
\hline & & $>1.000 .000$ & $\begin{array}{c}500.000 \\
\mathrm{~s} / \mathrm{d} \\
1.000 .000\end{array}$ & $\begin{array}{c}100.000 \\
\text { s/d } \\
500.000\end{array}$ & $\begin{array}{c}20.000 \\
s / d \\
100.000\end{array}$ & $<20.000$ \\
\hline & & $\begin{array}{c}\text { Kota } \\
\text { Metropolitan } \\
\end{array}$ & $\begin{array}{l}\text { Kota } \\
\text { Besar }\end{array}$ & $\begin{array}{c}\text { Kota } \\
\text { Sedang }\end{array}$ & Kota Kecil & Desa \\
\hline 1 & $\begin{array}{l}\text { Konsumsi Unit Sambungan } \\
\text { Rumah (SR) (ltr/org/hari) }\end{array}$ & $>150$ & $150-120$ & $90-120$ & $80-120$ & $60-80$ \\
\hline 2 & $\begin{array}{l}\text { Konsumsi Unit Hidran Umum } \\
\text { (HU) (ltr/org/hari) }\end{array}$ & $20-40$ & $20-40$ & $20-40$ & $20-40$ & $20-40$ \\
\hline 3 & Faktor hari maksimum & $\begin{array}{c}1.15-1.25 \\
* \text { harian }\end{array}$ & $\begin{array}{c}1.15-1.25 \\
* \text { harian }\end{array}$ & $\begin{array}{c}1.15-1.25 \\
* \text { harian } \\
\end{array}$ & $\begin{array}{c}1.15-1.25 \\
* \text { harian } \\
\end{array}$ & $\begin{array}{c}1.15-1.25 \\
* \text { harian }\end{array}$ \\
\hline 4 & Faktor jam puncak & $\begin{array}{l}1.75-2.0 \\
* \text { hari maks }\end{array}$ & $\begin{array}{r}1.75-2.0 \\
* \text { hari maks } \\
\end{array}$ & \begin{tabular}{|c|}
$1.75-2.0$ \\
${ }^{*}$ hari maks \\
\end{tabular} & $\begin{array}{r}1.75-2.0 \\
* \text { hari maks } \\
\end{array}$ & $\begin{array}{l}1.75-2.0 \\
* \text { hari maks }\end{array}$ \\
\hline 5 & Jumlah jiwa per SR (Jiwa) & 5 & 5 & 5 & 5 & 5 \\
\hline 6 & Jumlah jiwa per HU (Jiwa) & 100 & 100 & 100 & $100-200$ & 200 \\
\hline 7 & $\begin{array}{l}\text { Sisa tekan di penyediaan } \\
\text { distribusi (meter) }\end{array}$ & 10 & 10 & 10 & 10 & 10 \\
\hline 8 & Jam operasi (jam) & 24 & 24 & 24 & 24 & 24 \\
\hline 9 & $\begin{array}{l}\text { Volume reservoir } \\
(\% \text { max day demand })\end{array}$ & $15-25$ & $15-25$ & $15-25$ & $15-25$ & $15-25$ \\
\hline 10 & SR : HU & $\begin{array}{c}50: 50 \\
s / d \\
80: 20 \\
\end{array}$ & $\begin{array}{c}50: 50 \\
s / d \\
80: 20 \\
\end{array}$ & $80: 20$ & $70: 30$ & $70: 30$ \\
\hline
\end{tabular}

Sumber: Kriteria Perencanaan Ditjen Cipta Karya Dinas PU, 1996. (11).

\section{Hasil Survei Pemakaian Air Bersih, Sanitasi dan Presepsi Masyarakat}

Dari hasil input data dan analisa deskritif dengan menggunakan bantuan SPSS versi 21, diperoleh grafik-grafik hasil analisa seperti di bawah ini. Berikut ini akan diuraikan hasil analisa berdasarkan pengelompokan pertanyaan, yaitu :

\section{Tingkat Pendidikan}

Sebagian besar responden mempunyai tingkat pendidikan tamatan SLTA (60\%) kemudian tamatan Sekolah Dasar dan SLTP (13,3\%), kemudian diikuti lulusan Pendidikan Tinggi/Akademi sebesar $6,7 \%$ dan yang tidak mencapai tingkat SD hanya $6,7 \%$. Tingginya lulusan SLTA bukan berarti tidak mampu melanjutkan ke perguruan tinggi tetapi faktor minat (12), meskipun pihak perusahaan telah menawarkan untuk beasiswa $\mathrm{S} 1$ dan $\mathrm{S} 2$ kepada penduduk Desa Kawasi melalui program CSR (13). Mereka lebih ingin bisa langsung bekerja, sebagian penduduk Desa Kawasi bekerja di beberapa perusahaan tambang dan perusahaan rekanannya.

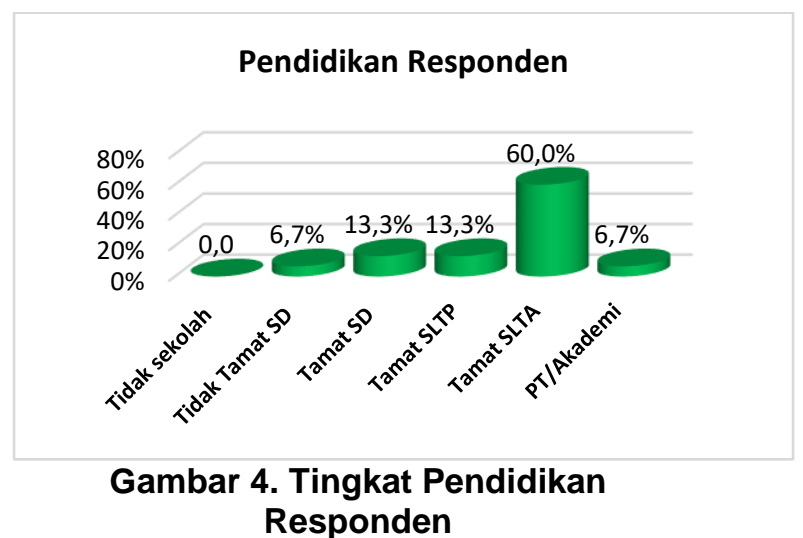

\section{Mata Pencaharian}

Mata pencaharian penduduk Desa Kawasi di sekitar Danau Karo bervariasi mulai dari buruh, petani sampai pegawai negeri atau swasta. Sebagian besar responden mempunyai pekerjaan sebagai pegawai swasta $(46,7 \%)$ umumnya mereka bekerja di perusahaan-perusahaan yang berhubungan dengan tambang nikel, kemudian diikuti oleh pedagang (26,7\%). Mata pencaharian lainnya adalah sebagai buruh swasta yang bekerja di perusahaan pertambangan $(20,0 \%)$ dan sebagian kecil 
adalah petani perkebunan (6,7\%). erusahaan tambang memberikan kesempatan kerja bagi masyarakat desa (14).

\section{Mata Pencaharian Penduduk}

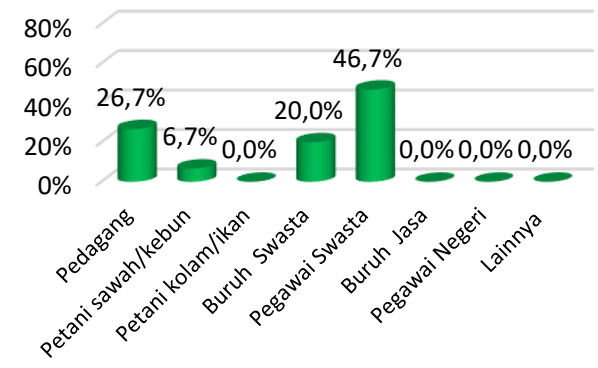

\section{Gambar 5. Mata Pencaharian Warga}

\section{Penggunaan Air Bersih}

\section{a. Sumber air minum}

Sumber air untuk digunakan sebagai air minum sebagian besar $(46,7 \%)$ warga berasal dari mata air Kawasi. Selain itu banyak warga (40\%) juga membeli air untuk kebutuhan air minumnya. Hanya sebagian kecil warga $(13,3 \%)$ yang mengambil sumber air dari sumur pribadi sebagai air minum. Secara kualitas maupun kuantitas air dari mata air Kawasi sangat bagus, hal ini telah dibahas diatas tentang kondisi mata air Kawasi. Meskipun sebagian besar potensi air dari mata air Kawasi masih terbuang ke laut.

\section{Sumber Air Minum yang Digunakan}

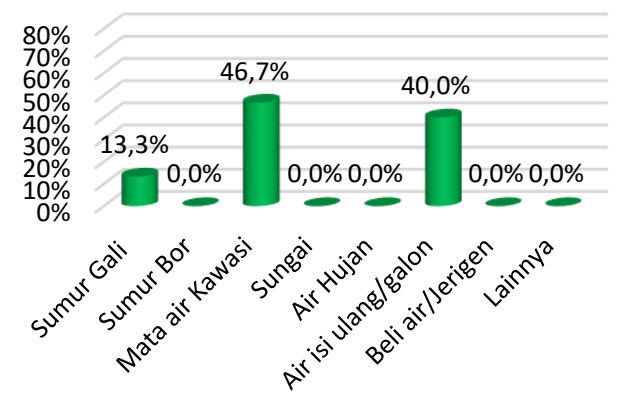

Gambar 6. Sumber Air untuk Minum b. Penurunan Debit mata Air Kawasi

Sebagian besar responden (66,7\%) menyatakan bahwa telah terjadi penurunan debit air dari sumber mata air Kawasi selama musim kemarau ini. Perlu dibuat bak penampung yang cukup besar untuk menampung air dari mata air Kawasi sehingga tidak semua air tersebut terbuang percuma ke laut.

\section{Debit Mata Air Kawasi Menurun}

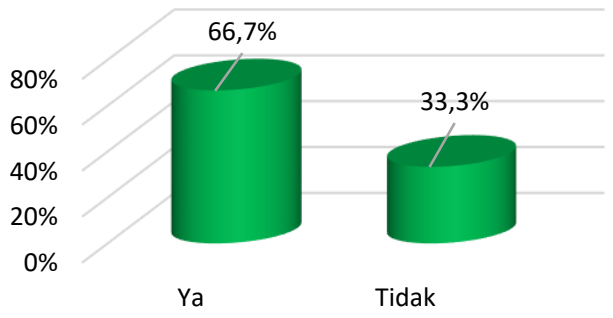

\section{Gambar 7. Debit Mata Air Kawasi Pernah Berkurang}

\section{c. Jika Membeli Berapa Liter Per Bulan}

Dari sebagian warga yang membeli air untuk kebutuhan air minumnya, sebagian besar $(73,3 \%)$ mereka membeli air dengan jumlah kurang dari 100 sampai 200 liter per bulannya. Hanya sebagian kecil $(26,7 \%)$ saja warga yang membeli air di bawah 100 liter perbulannya. Warga membeli air untuk air minum dengan menggunakan botol galon.

\section{Jumlah Air Minum yang dibeli perbulan}

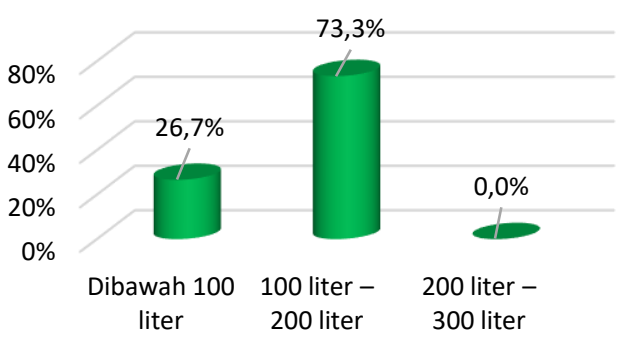

Gambar 8. Jumlah air untuk minum yang dibeli 


\section{d. Sumber Air untuk Mandi, Cuci dan Kakus (MCK)}

Sumber air untuk digunakan warga mandi, cuci dan kakus (MCK), sebagian besar bersumber dari mata air Kawasi (80\%) dan sumur gali (20\%). Selebihnya warga mengambil dari air danau (air Danau Karo) untuk kebutuhan MCK.

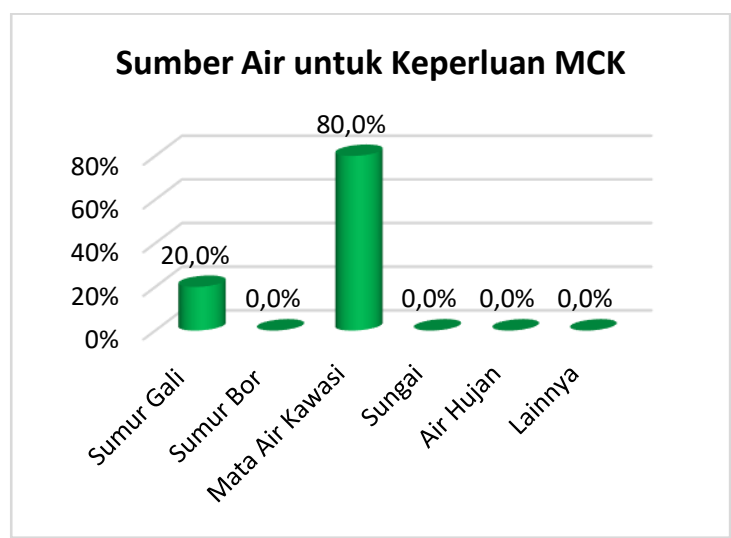

\section{Gambar 9. Sumber Air untuk MCK}

\section{Sanitasi Lingkungan}

\section{a. Septik Tank}

Septik tank adalah tempat pembuangan kotoran tinja yang tidak boleh disalurkan ke pembuangan umum atau sungai. Sebagian besar $(86,7 \%)$ warga sudah mempunyai septik tank sendiri. Pembuatan septik tank berfungsi untuk mencegah timbulnya penyakit perut menular seperti tifus, kolera, disentri dan sebagainya, yang menyebar melalui tinja/feses atau kotoran manusia (15).

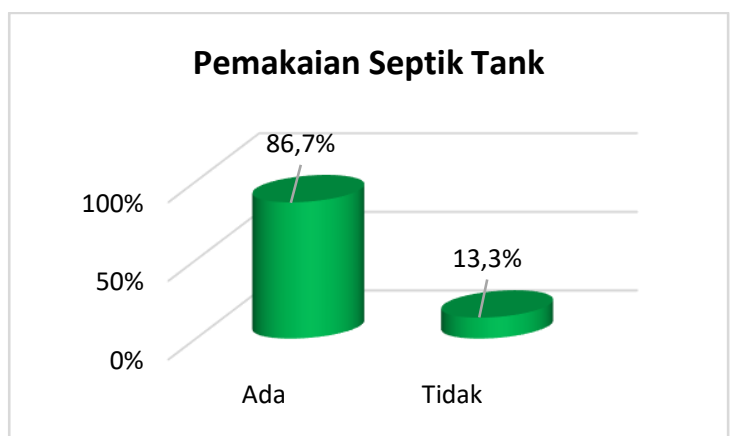

Gambar 10. Keberadaan Septik Tank

\section{b. Tempat Kakus}

Sebagian besar $(93,3 \%)$ warga sudah mempunyai toilet atau WC pribadi untuk buang air besar (BAB), hanya sebagian kecil $(6,7 \%)$ saja warga melakukan $B A B$ di WC untuk umum. Ini menunjukkan bahwa kesadaran warga akan pentingnya kesehatan lingkungan sudah tinggi. Keberadaan WC pribadi ini tidak lepas dari ketersediaan air bersih yang memadai di desa tersebut.

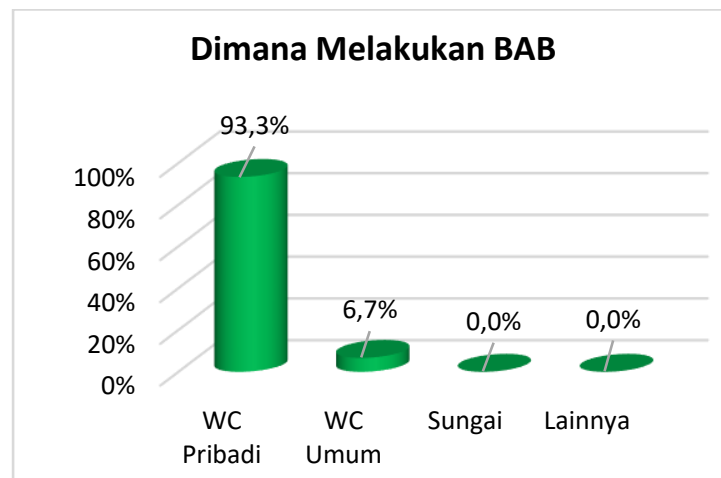

\section{Gambar 11. Dimana melakukan Buang Air Besar}

\section{Kesehatan Warga}

a. Pengaruh Pertambangan Terhadap Kesehatan Warga

Sebagian besar (60\%) warga menyatakan bahwa pengaruh adanya pertambangan terhadap kesehatan adalah gangguan pernafasan dan batuk-batuk $(26,7 \%)$ yang ada selama ini. Hanya sebagian kecil warga $(13,3 \%)$ menyatakan tidak ada pengaruh terhadap kesehatan mereka. Pada penelitian lain menunjukkan bahwa akibat penambangan nikel dapat menimbulkan pencemaran udara berupa debu, khususnya pada musim kemarau (16). 
Pengaruh Tambang Terhadap Kesehatan



\section{Gambar 12. Pengaruh adanya pertambangan terhadap Warga}

\section{b. Fasilitas Pengobatan Yang Digunakan}

Fasilitas pengobatan yang paling banyak $(46,7 \%)$ digunakan warga desa adalah Puskemas (Poliklinik Desa) Desa baik yang berada di Kecamatan maupun Puskesmas Pembantu yang berada di Desa Kawasi. Sebagian warga melakukan pengobatan sendiri dan pengobatan alternatif. Hanya sedikit warga yang melakukan pengobatan lainnya seperti datang ke poliklinik yang berada di kawasan perusahaan pertambangan karena lokasi cukup jauh dari pemukiman. Masyarakat desa juga mendapat bantuan program kesehatan dari program CSR perusahaan tambang di sekitar desa tersebut.

\section{Dimana Tempat Pengobatan Anda}

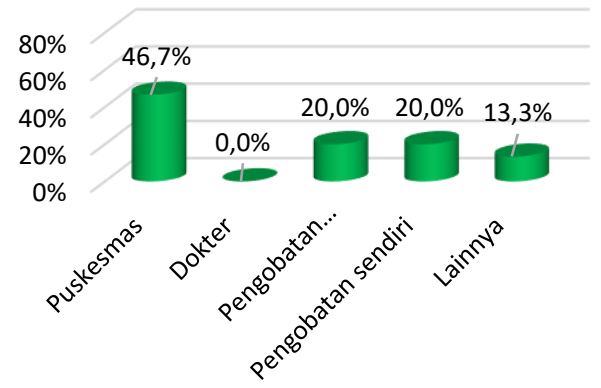

Gambar 13. Fasilitas Pengobatan Yang Digunakan Warga

\section{KESIMPULAN}

Berdasarkan hasil penelitian LAPI ITB sumber mata air Kawasi mempunyai debit 138 liter/detik pada tahun 2018 dan pada pada waktu survei pada tahun 2019 debitnya menurun menjadi 119 liter/detik. Kualitas air mata air ini pada tahun 2019 dengan konsentrasi parameter fisika dan kimia yang tidak melebihi baku mutu peraturan Menteri Kesehatan RI No. 32 tahun 2017 yaitu dengan nilai TDS sebesar 92 $\mathrm{mg} / \mathrm{l}$, kekeruhan sebesar $0.02 \mathrm{mg} / \mathrm{l}$, fluorida sebesar $0.030 \mathrm{mg} / \mathrm{l}$ dan sulfat sebesar 0.54 $\mathrm{mg} / \mathrm{l}$. Sedangkan total coliform masih jauh di bawah baku mutu yang ditetapkan. Secara keseluruhan kualitas air mata air Kawasi masih sangat baik.

Dari analisa kebutuhan air penduduk untuk kebutuhan air domestik, non domestik serta kehilangan air, maka kebutuhan total air penduduk Desa Kawasi pada tahun 2035 dan 2040 adalah sebesar 1,6599 liter/detik dan 1,9642 liter/detik

Sumber air untuk digunakan sebagai air minum sebagian besar $(46,7 \%)$ warga berasal dari mata air Kawasi, yang membeli air $(40 \%)$ dan sisanya mengambil sumber air dari sumur. Sumber air untuk digunakan warga mandi, cuci dan kakus (MCK), sebagian besar bersumber dari mata air Kawasi (80\%), sumur gali $(20 \%)$ dan selebihnya mengambil dari air danau Karo. Sebagian besar (86,7\%) warga sudah mempunyai sistem pengolahan tinja dengan WC pribadi/toilet berjumlah $93,3 \%$.

Sebagian besar (60\%) warga menyatakan bahwa pengaruh adanya pertambangan terhadap kesehatan adalah gangguan pernafasan dan batuk-batuk $(26,7 \%)$. Hanya sebagian kecil warga $(13,3 \%)$ menyatakan tidak ada pengaruh terhadap kesehatan mereka.

\section{PERSANTUNAN}

Ucapan terima kasih untuk Direktur PTL dan para penelitinya yang telah membantu kegiatan ini dari awal hingga akhir. Selain itu kami juga mengucapkan terima kasih kepada pihak-pihak lain yang mendukung kegiatan ini. 


\section{DAFTAR PUSTAKA}

G. A. Kambo. (2015). Etnisitas Dalam Otonomi Daerah. The POLITICS: Jurnal Magister Ilmu Politik Universitas Hasanuddin Volume 1, Number 1, Hal.: $1-8$.

Anonim. (2020). Studi Penataan Keberlanjutan Kuantitas Air Danau Karo di Pulau Obi Halmahera Selatan. Laporan PT HPL-BPPT.

Anonim, (2019). Kecamatan Obi Dalam Angka 2019. Badan Pusat Statistik, Kab. Halmahera Selatan.

Anonim, (2018). Studi Hidrogeologi Mata Air Kawasi, Pulau Obi, Maluku Utara. Laporan PT TBP dan PT. LAPI ITB.

A. Norhadi, A. Marzuki, L. Wicaksono, R.A. Yacob. (2015). Studi Debit Aliran Pada Sungai Antasan Kelurahansungai Andai Banjarmasin Utara. Jurnal POROS TEKNIK, Vol. 7, No. 1 Hal.:1-53.

Anonim. (2017). Peraturan Menteri Kesehatan Republik Indonesia Nomor 32 Tahun 2017 Tentang Standar Baku Mutu Kesehatan Lingkungan Dan Persyaratan Kesehatan Air Untuk Keperluan Higiene Sanitasi, Kolam Renang, Solus Per Aqua, Dan Pemandian Umum.

Anonim. (2019). Modul 3 Hidrogeologi. Pelatihan Teknologi Geolistrik 2 Dimensi untuk Perencanaan Pemanfaatan Potensi AirTanah. Badan Pengembangan Sumder Daya Manusia, PUPR.

Anonim, 2017, "Kecamatan Obi Dalam Angka 2017", Badan Pusat Statistik Kabupaten Halmahera Selatan.

F.D. Anggraini, Samadi, Warnadi. (2013). Pengaruh Pertumbuhan Penduduk Terhadap Kebutuhan Air Bersih di Pulau Panggang, Kelurahan Pulau Panggang, Kecamatan Kepulauan Seribu, Provinsi DKI Jakarta. Jurnal SPATIAL. Vol. 12, No. 2. Hal.:25-30.

Hartati, Indrawati, R. Sitepu, N. Tamba. (2016). Metode Geometri, Metode Aritmatika Dan Metode Eksponensial Untuk Memproyeksikan Penduduk Provinsi Sumatera Selatan. Prosiding
Seminar Nasional Sains Matematika Informatika dan Aplikasinya IV Fakultas MIPA Universitas Lampung, Vol. 4 Buku 4. Hal.: 7-18.

D.S. Krisnayanti, I.M. Udiana, H.J. Benu. (2013). Studi Perencanaan Pengembangan Penyediaan Air Bersih Di Kecamatan Kupang Timur Kabupaten Kupang. Jurnal Teknik Sipil, Vol. II. No. 1. Hal.:71-85.

W. A. Apriyani, A. Sastrawan, R. Rosyid. (2016). Analisis Faktor Penyebab Siswa Lulusan Sma Tidak Melanjutkan Ke Perguruan Tinggi Di Sintang. Jurnal Pendidikan dan Pembelajaran Khatulistiwa. Vol. 7, No. 7. Hal.:1-10.

E. Saroa, L.C. Mandey, S. Mandey. (2016). Implementasi Kebijakan Corporate Social Responsibility Pada PT. Trimegah Bangun Persada Di Desa Kawasi Kecamatan Obi Kabupaten Halmahera Selatan. Jurnal IImu Sosial \& Pengelolaan Sumberdaya Pembangunan, Edisi XXI, hal.:34-48.

Anonim, (2019). PT Harita Nickel Bantah Disnaker. Available from (Diakses 2-102020;09:45)

https://www.kabartimurnews.com/2019/ 02/13/pt-harita-nickel-bantahpernyataan-disnaker/

S. Hassan. (1992). Ensiklopedi Indonesia. PT Ichtiar Bam-Van Hoeve, Jakarta.

S. Aldiansyah, L. O. Nursalam. (2019). Dampak Pertambangan Nikel Pt.Ifishdeco Terhadap Kondisi Lingkungan Hidup Di Desa Roraya Kecamatan Tinanggea Kabupaten Konawe Selatan Jurnal Penelitian Pendidikan Geografi Vol. 4 No. 1, hal: 105-122. 